\title{
Can nanolites enhance eruption explosivity?
}

Francisco Cáceres ${ }^{1}$, Fabian B. Wadsworth ${ }^{2,3}$, Bettina Scheu ${ }^{1}$, Mathieu Colombier ${ }^{1}$, Claudio Madonna $^{4}$, Corrado Cimarelli ${ }^{1}$, Kai-Uwe Hess ${ }^{1}$, Melanie Kaliwoda ${ }^{5}$, Bernhard Ruthensteiner ${ }^{6}$, Donald B. Dingwell ${ }^{1}$

${ }^{1}$ Department of Earth and Environmental Sciences, Ludwig-Maximilians-Universität, Theresienstr. 41, 80333 Munich, Germany. ${ }^{2}$ Department of Earth Sciences, Durham University, U.K. ${ }^{3}$ Centre for Advanced Studies, Ludwig-Maximilians-Universität, Munich, Germany. ${ }^{4}$ Department of Earth Sciences, ETH Zürich, Switzerland. ${ }^{5}$ Mineralogical State Collection Munich, Germany. ${ }^{6}$ Zoologische Staatssammlung, Munich, Germany.

\section{Data Repository}

This data repository contains:

(1) Extended methods

(2) Figure DR1. Raw experimental data

(3) Figure DR2. Water solubility model

(4) Figure DR3. Porosity calibration curve

(5) Figure DR4. SEM evidence for nanolites in natural sample

(6) Figure DR5. Gas volume fraction and bubble size in modeling

(7) Table DR1. Chemical composition of experimental materials

(8) Table DR2. Raw bubble number density $\left(N_{b}\right)$ data

(9) Table DR3. Extended references for compiled $N_{b}$ data

(10) Table DR4. Extended references for chemical composition of compiled $N_{b}$ data 


\section{EXTENDED METHODS}

\section{Samples and analyses}

In this study, we used a Fe-rich nanolite-free natural obsidian $\left(0.11-0.15 \mathrm{wt} \% \mathrm{H}_{2} \mathrm{O}\right.$; Tuffen and Castro, 2009) from Hrafntinnuhryggur eruption of Krafla volcano in Iceland and a synthesised Fe-Ti oxide-nanolite-rich glass with slightly higher water content $\left(0.32 \mathrm{wt} \% \mathrm{H}_{2} \mathrm{O}\right)$ of the same composition than the natural obsidian. $\mathrm{H}_{2} \mathrm{O}$ was determined approximately with Simultaneous Thermal Analysis (combined Differential Scanning Calorimetry and Thermogravimetry methods) using a NETZSCH® STA 449C Jupiter at LMU Munich, Germany. Natural obsidian is a homogeneous glass with very low crystal content ( $<1$ vol.\% of Fe-Ti oxide microlites) and bubble-free. The synthesis was conducted in a Hot Isostatic Press (HIP) at the Rock Physics and Mechanics Laboratory at the ETH Zurich, Switzerland, using fine powder $(<63 \mu \mathrm{m}$ diameter particles) of the same natural obsidian from Krafla that was crushed and then put into stainless-steel canisters internally covered by an Mo film to avoid chemical contamination from the canister to the powder and melt. The synthesis was conducted at controlled conditions of pressure $(23 \mathrm{MPa})$ and temperature $\left(800^{\circ} \mathrm{C}\right)$ during a 3 hour dwell time and then quenched at $\sim 40^{\circ} \mathrm{C} \mathrm{min}^{-1}$, so that the final glass is completely sintered and the P-T-t conditions and low water content of the sample allow the Fe-Ti oxide nanolites to form. The final synthesised glass is a homogeneously thoroughly-sintered sample with very low microlite content $(<1 \mathrm{vol} \%$ of Fe-Ti oxides) and $~ 2$ vol.\% of Fe-Ti oxide nanolites in the groundmass. Both staring materials were drilled out and cut into cylinders of $5 \mathrm{~mm}$-diameter and $3 \mathrm{~mm}$-length in order to conduct the experiments.

Samples were analysed under the scanning electron microscope (SEM) and a confocal Raman spectrometer at the LMU and the Mineral State Collection in Munich respectively, in order to confirm the absence and presence of nanolites in the case of the natural and synthesised samples respectively. The SEM conditions were $10-12 \mathrm{kV}, 0.1 \mathrm{~mA}$ and $5.5 \mathrm{~mm}$ working distance, where they were clearly visible at magnifications of x13,000 and higher. The Raman analyses were conducted on the glass of the natural obsidian and the groundmass of the synthesised sample following recommended conditions (Di Genova et al., 2017b). Nanolite and bubble number densities, as well as porosities were determined using the image analysis software FOAMS (Shea et al., 2010a) with binarized SEM images in the case of the synthesized samples and using in-built analysis functions in Avizo ${ }^{\mathrm{TM}}$ with X-ray computed tomography (CT) obtained with a GE-Instruments ${ }^{\mathrm{TM}}$ Phoenix Nanotom-M device from selected nanolite-free samples. Nanolite-bearing samples were not systematically analysed through CT because of the 
maximum spatial resolution that could be obtained according to the required contrast conditions was $2 \mu \mathrm{m}$ per pixel size and bubble films are in the order of $1 \mu \mathrm{m}$ thick (Fig. 1F). For this reason, individual bubbles could not be properly separated and no reliable value of $N_{b}$ could be obtained in $3 \mathrm{D}$, and so we opted to analyse the nanolite-bearing samples using 2D-based analysis techniques via SEM images.

A key outstanding question is why the natural sample did not have nanolites while the resintered synthetic sample did. We speculate that this is because the natural sample preserves highly reduced iron oxidation state (Casas et al., 2019), which is not conducive to Fe-Ti nanolite crystallization (Di Genova et al., 2017b). However, the dwell time at elevated temperature during re-sintering and synthesis of what became the nanolite-bearing sample provided time for iron oxidation state equilibration at elevated oxygen fugacity, bringing the sample into the nanolite crystallization window. However, as we note in the main text, nanolite nucleation conditions require further investigation.

\section{Experiments}

They were conducted isobarically (1 bar) in an Optical Dilatometer at LMU Munich, Germany. Samples were heated up from ambient temperature $\left(\sim 23^{\circ} \mathrm{C}\right)$ at controlled heating rates between 1 and $60{ }^{\circ} \mathrm{C} \min ^{-1}$ and kept at final targeted temperatures of $820-1000^{\circ} \mathrm{C}$ between 0 and 840 minute dwell times. This procedure allows us to record porosity variations with time while expansion occurs driven by vesiculation. The $2 \mathrm{D}$ areas of samples in silhouette cross section were converted to volume by applying solid of rotation to a cylinder with equivalent area and height. The size of the cores as well as the position of the samples placed in the optical dilatometer ensure a homogeneous heating of the sample and precise measurement of the sample temperatures $\left( \pm 2^{\circ} \mathrm{C}\right)$. Porosity calculations were tested through a wide range of porosities (0.06-0.80) against that obtained with Computed Tomography (CT) analyses of selected samples and other rhyolitic samples submitted at the same conditions to those in this study samples. We determined that the error for porosity calculated with the optical dilatometer is \pm 0.02 (Fig. DR3), which is a good trackable real-time determination of porosity within the range obtained.

\section{Conduit modelling}

The published model of Degruyter et al. (2012) was used in order to show what effect an increase in the bubble number density can cause in an ascending rhyolitic magma. The original model code solution was provided by Wim Degruyter. Similar to previous models (e.g. Mastin, 
2002), this is a 1-dimensional 2-phase model for steady flow in a volcanic conduit. Crucially, this model implements the effect of outgassing via the development of magma permeability in the shallow conduit once magma reaches a critical percolation threshold of porosity. Above this point, outgassing affects the evolution of gas pressure and is a more realistic model for gas-melt ascent in the crust than previously achieved ones (c.f. Mastin, 2002). For details of the governing equations and solution method, we refer the reader to Degruyter et al. (2012). Here we give the input parameters used in our scenario solution:

We take a conduit of length $5 \mathrm{~km}$, an isothermal magma temperature of $825^{\circ} \mathrm{C}$, an initial water concentration of $4.27 \mathrm{wt} . \%$, an initial driving pressure of $120 \mathrm{MPa}$, and an initial bubble size of $10^{-7} \mathrm{~m}$ which are conditions designed to be consistent with an eruption similar to Chaitén 2008 (based on Castro \& Dingwell, 2009). For each model run, we varied the number density of bubbles in order-of-magnitude steps from $N_{b}=10^{4} \mathrm{~mm}^{-3}$ to $N_{b}=10^{9} \mathrm{~mm}^{-3}$ (6 runs), and we then repeated each suite of those 6 runs for 3 different conduit diameters of $C_{d}=$ $10 \mathrm{~m}, C_{d}=16 \mathrm{~m}$ and $C_{d}=20 \mathrm{~m}$ (resulting in a total number of 18 model simulation runs), which approximately encapsulates the end-member uncertainties on the conduit dimension feeding eruptions such as the 2008 eruption of Chaitén (e.g. Castro \& Dingwell, 2009). For all other parameters (e.g. initial bubble size, permeability model formulation etc), we used the default parameters used by Degruyter et al. (2012), which were selected for applications to similar large silicic eruptions.

In each simulation run, we identify fragmentation as the discontinuous jump in the output of porosity, pressure, or velocity with depth. These jumps in the output solutions represent the transition from magma continuum with a disperse gas phase (at large depths in the conduit) to a gas continuum with a dispersed melt phase (at small depths in the conduit). This fragmentation transition is not seen in all runs (see main text). 

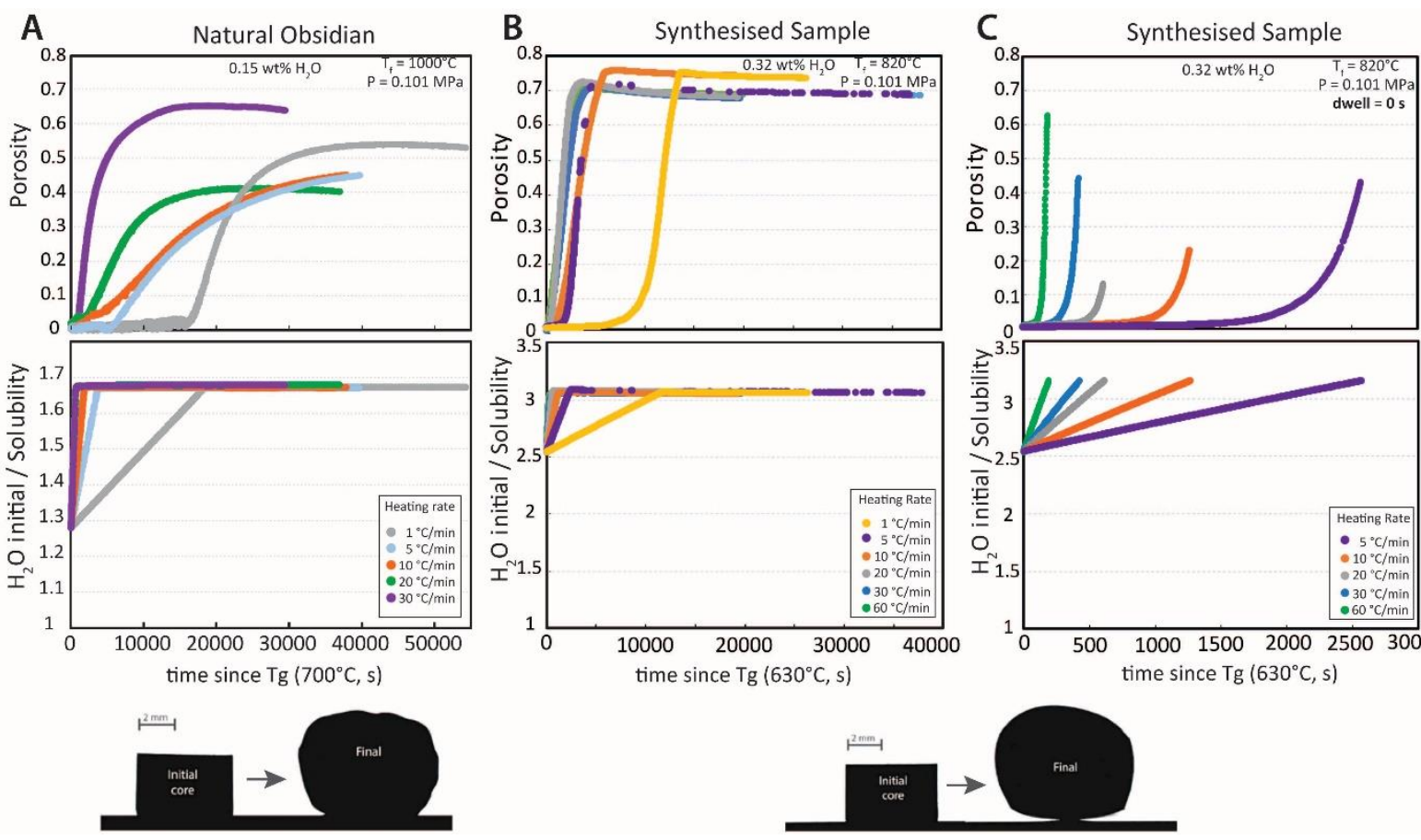

Figure DR1. Real time vesiculation profiles for: (A) natural (nanolite-free) and (B-C) synthesised (nanolite-rich) samples, together with the evolution of the ratio of the initial $\mathrm{H} 2 \mathrm{O}$ concentration and the $\mathrm{H} 2 \mathrm{O}$ solubility. Initital $\mathrm{H} 2 \mathrm{O}$ is measured value from STA analyisis (see Extended Methods), and the $\mathrm{H} 2 \mathrm{O}$ solubility is computed using Liu et al. (2005) solubility model valid for rhyolites and for which 1 bar pressure was input. (C) Represents experiments conducted with only a heating phase (without dwell time at maximum temperature). Bottom silhouette images represent the sample images acquired from the optical dilatometer at the beginning and end (final porosity) of the heating program of a representative sample of each kind, from which volumes are computed continuously. 


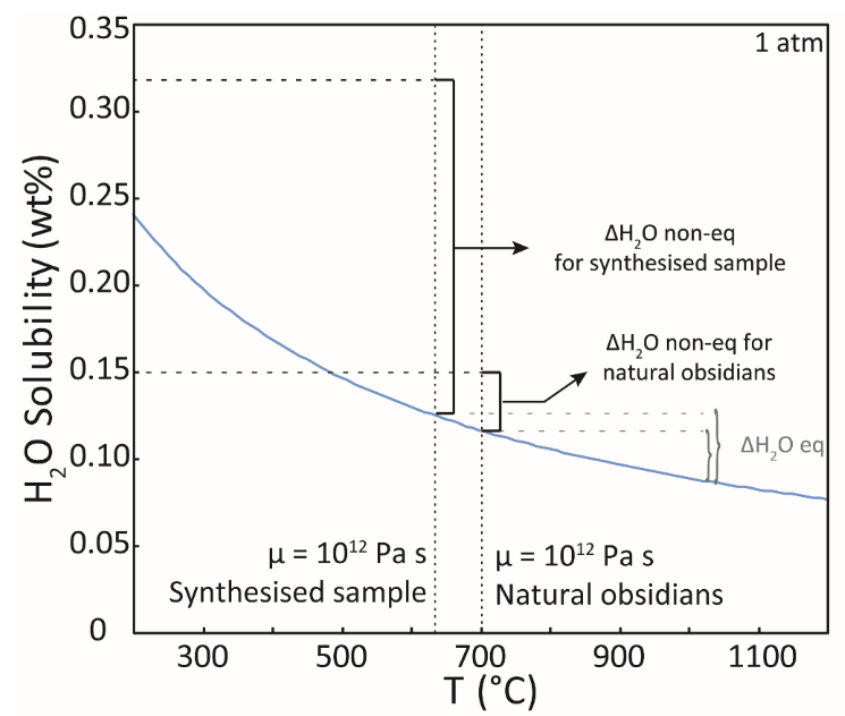

Figure DR2. Water solubility curve for rhyolitic magmas at 1 atm. Vertical dotted lines show the glass transition temperature $(\mathrm{Tg})$ for both the synthesised sample and the natural obsidian. Gray keys show the water exsolved $\left(\Delta \mathrm{wt} \% \mathrm{H}_{2} \mathrm{O}\right)$ in equilibrium conditions dependent of the final temperature. Black keys show the supersaturation level and hence the amount of water exsolved in non-equilibrium conditions after crossing Tg during heating. Solubility model of Liu et al. (2005). Viscosity model of Hess and Dingwell (1996). 


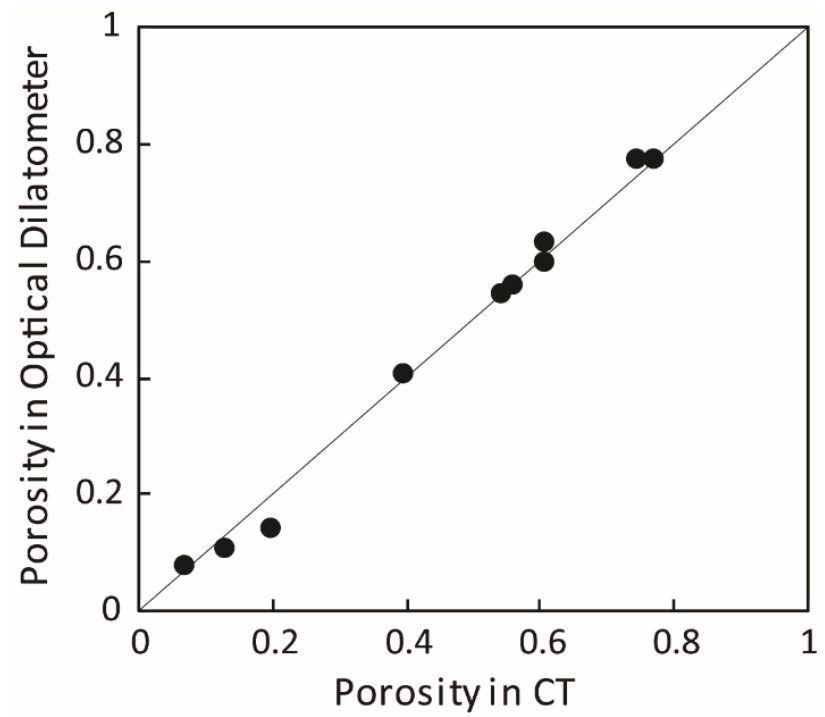

Figure DR3. Comparison of porosity determined with optical dilatometer method versus tomography. 1:1 line is shown as reference. Deviation is 0.02 (or 2 vol.\% vesicularity). 


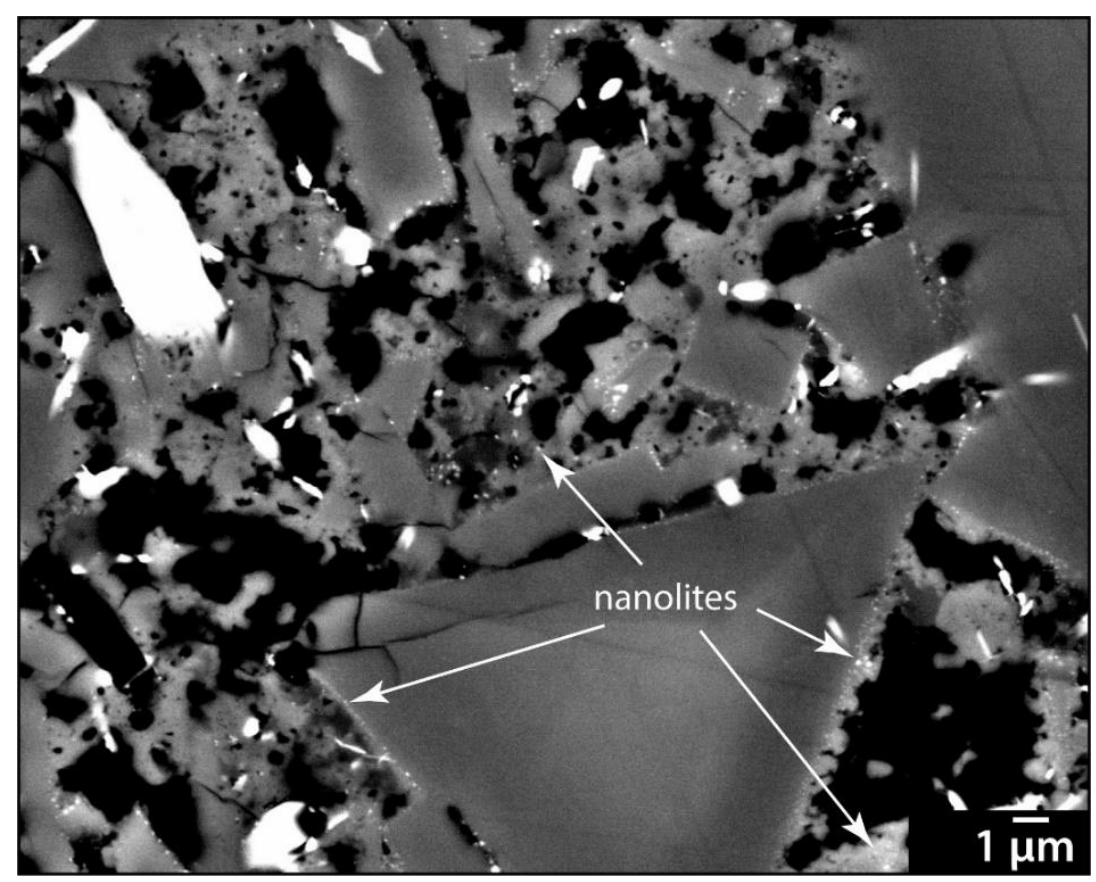

Figure DR4. Sample from Kilian volcano (U1) with high $N_{b}\left(\sim 10^{8} \mathrm{~mm}^{-3}\right)$ and nanolites. Modified from Colombier et al. (2017b). 

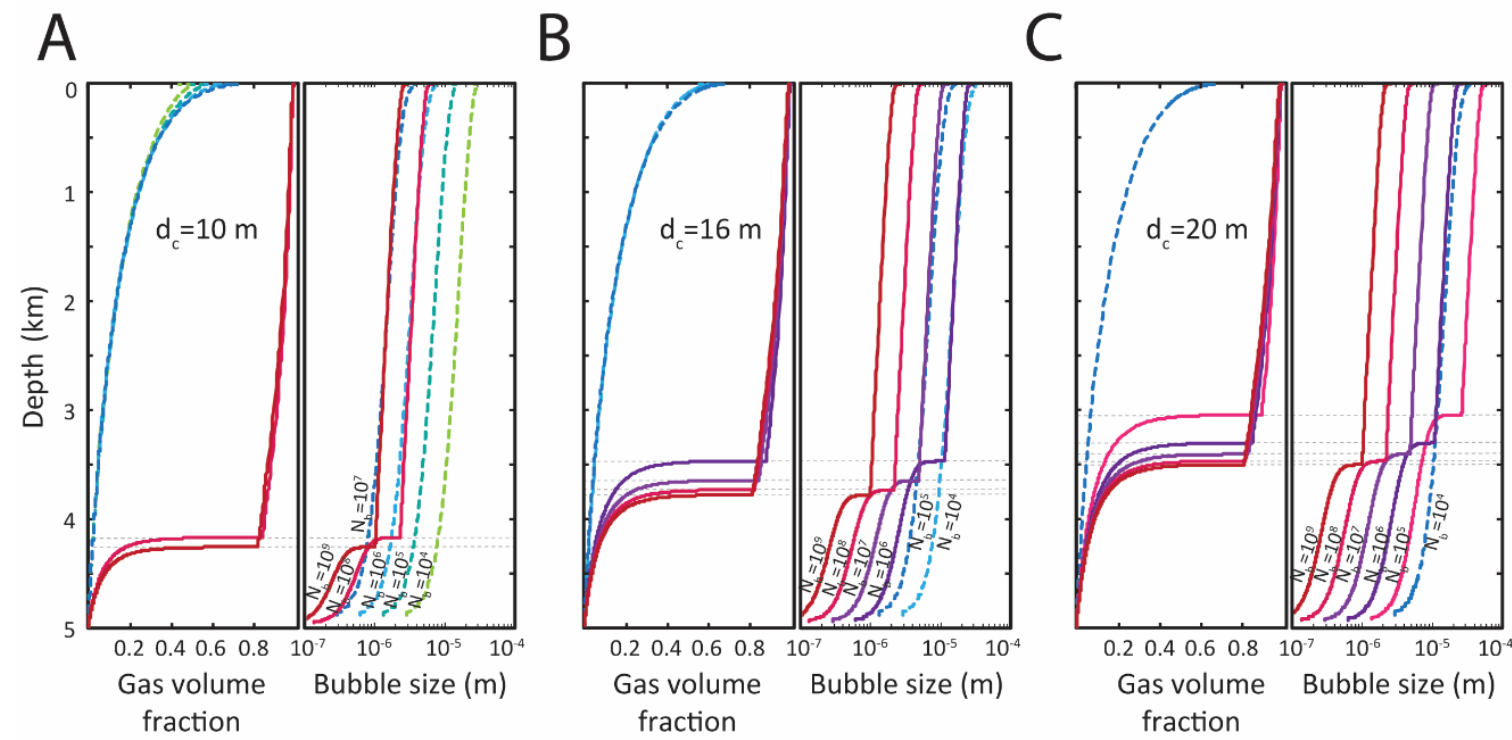

Figure DR5. Gas volume fraction and bubble size evolution for a rhyolitic magma ascending in a conduit of: (A) $10 \mathrm{~m}$, (B) $16 \mathrm{~m}$, and (C) $20 \mathrm{~m}$ diameter. Results are shown varying bubble number density $\left(N_{b}\right)$ between $10^{4}-10^{9} \mathrm{~mm}^{-3}$. Effusive eruptions are in dotted lines and explosive eruptions in solid lines. Fragmentation level is marked as a grey dotted line. Model used was that of Degruyter et al. (2012). For details of modeling see main text. Bubble size was calculated following Cassidy et al. (2018). 
Table DR1. Chemical composition of synthesised sample (nanolite-bearing) and natural obsidian (nanolite-free). Data represents the average of 10 points $(n=10)$ measured on the groundmass and normalised to a water-free basis.

\begin{tabular}{ccc}
\hline Oxides (wt\%) & Synthesised sample & Natural obsidian \\
\hline $\mathrm{SiO}_{2}$ & 75.46 & 75.34 \\
$\mathrm{TiO}_{2}$ & 0.21 & 0.26 \\
$\mathrm{Al}_{2} \mathrm{O}_{3}$ & 12.17 & 12.11 \\
$\mathrm{FeO}^{\top}$ & 3.24 & 3.34 \\
$\mathrm{MnO}$ & 0.14 & 0.10 \\
$\mathrm{MgO}$ & 0.09 & 0.11 \\
$\mathrm{CaO}$ & 1.73 & 1.73 \\
$\mathrm{Na}_{2} \mathrm{O}$ & 4.19 & 4.28 \\
$\mathrm{~K}_{2} \mathrm{O}$ & 2.75 & 2.72 \\
$\mathrm{P}_{2} \mathrm{O}_{5}$ & 0.02 & 0.01 \\
\hline
\end{tabular}


Table DR2. Bubble number densities for experimental conditions.

\begin{tabular}{cccccc} 
Sample & Type & Heating rate $\left({ }^{\circ} \mathbf{C ~} \mathbf{~ m i n}^{-1}\right)$ & Dwell temperature $\left({ }^{\circ} \mathbf{C}\right)$ & $\mathbf{N b}^{\mathbf{A}}\left(\mathbf{m m}^{-3}\right)$ & $\mathbf{~ N b}^{\mathbf{B}}\left(\mathbf{m m}^{-3}\right)$ \\
\hline Kb2-OD-03 & nanolite-bearing & 20 & 1000 & $5.95 \times 10^{6}$ & - \\
Kb2-OD-06 & nanolite-bearing & 30 & 850 & $5.58 \times 10^{7}$ & - \\
Kb2-OD-14 & nanolite-bearing & 30 & 845 & $8.06 \times 10^{7}$ & - \\
Kb2-OD-15 & nanolite-bearing & 5 & 820 & $8.46 \times 10^{6}$ & - \\
Kb2-OD-16 & nanolite-bearing & 10 & 820 & $1.79 \times 10^{6}$ & - \\
Kb2-OD-18 & nanolite-bearing & 1 & 820 & $5.33 \times 10^{6}$ & - \\
Kb2-OD-20 & nanolite-bearing & 60 & 820 & $1.48 \times 10^{7}$ & - \\
Kb2-OD-21 & nanolite-bearing & 30 & 820 & $2.45 \times 10^{7}$ & - \\
Ka-OD-02 & nanolite-free & 30 & 950 & - & $1.47 \times 10^{1}$ \\
Ka-OD-03 & nanolite-free & 30 & 1000 & - & $7.90 \times 10^{0}$ \\
Ka-OD-04 & nanolite-free & 30 & 975 & - & $6.51 \times 10^{0}$ \\
Ka-OD-08 & nanolite-free & 5 & 1000 & $2.39 \times 10^{0}$ & - \\
Ka-OD-10 & nanolite-free & 20 & 1000 & $8.64 \times 10^{-1}$ & - \\
Ka-OD-14 & nanolite-free & 1 & 1000 & $5.97 \times 10^{0}$ & - \\
Ka-OD-17 & nanolite-free & 30 & 1000 & - & $1.52 \times 10^{\circ}$ \\
Ka-OD-19 & nanolite-free & 10 & 1000 & - & $1.63 \times 10^{-1}$ \\
\hline
\end{tabular}

${ }^{\mathrm{A}} \mathrm{N}_{\mathrm{b}}$ melt corrected measured with FOAMS (Shea et al., 2010) from 2D SEM-BSE images.

${ }^{\text {В }} \mathrm{N}_{\mathrm{b}}$ melt corrected measured with Avizo ${ }^{\mathrm{TM}}$ from $3 \mathrm{D} \mu \mathrm{CT}$ reconstructions. 
Table DR3. Reference list for bubble number density data compilation.

Short Reference for Nb Eruption

\begin{tabular}{|c|c|}
\hline Adams et al., 2006a & Novarupta 1912 II-III, Alaska, USA \\
\hline Adams et al., 2006b & Novarupta 1912 V R1, Alaska, USA \\
\hline Alfano et al., 2012 & Chaitén 2008, Chile \\
\hline Campagnola et al. (2016) & Green Tuff Pantelleria 45ka, Italy \\
\hline Carey et al., 2009 & Askja 1875, Iceland \\
\hline Cioni et al. 2011 & Vesuvius 512, Italy \\
\hline Colombier et al., 2017b & Kilian 9.4 ka, France \\
\hline Giachetti et al. 2010 & Montserrat 1997, UK \\
\hline Gurioli et al., 2005 & Vesuvius 79 , Italy \\
\hline Houghton et al. 2010 & Taupo 181, New Zealand \\
\hline Klug \& Cashman 1994 & Mt St Helens 1980, Washington, USA \\
\hline Klug et al., 2002 & Mt Mazama 7.7 ka, Oregon, USA \\
\hline Nakamura 2006 & Sakurajima 1914-1915, Japan \\
\hline Polacci et al. 2001 & Pinatubo 1991, Philippines \\
\hline Polacci et al., 2003 & Campanian Ignimbrite $39 \mathrm{ka}$, Italy \\
\hline Rosi et al. 2004 & Quilotoa 800 BP, Ecuador \\
\hline Rotella et al., 2014 & Raoul-Matatirohia (3.7 ka), New Zealand \\
\hline Rotella et al., 2014 & Raoul-Oneraki (3.15 ka), New Zealand \\
\hline Rotella et al., 2014 & Raoul-Fleetwood (2.2 ka), New Zealand \\
\hline Rotella et al., 2015 & Raoul SW volcano Holocene, New Zealand \\
\hline Rotella et al., 2015 & Healy (recent), New Zealand \\
\hline Rotella et al., 2015 & Havre 2012, New Zealand \\
\hline Shea et al., $2010 b$ & Vesuvius 79, Italy \\
\hline Shea et al., 2012 & Vesuvius 79 , Italy \\
\hline Shea 2017 & Pinatubo 1991, Philippines + Campanian Ignimbrite 39ka, Italy \\
\hline Suzuki \& Nakada 2002 & Usu 2000, Japan \\
\hline Cáceres et al., 2018 & Laguna del Maule (rle, rln) Holocene rhyolitic lava flows, Chile \\
\hline Colombier et al., $2017 \mathrm{~b}$ & Kilian 9.4 ka (effusive inferred*), France \\
\hline Degruyter et al., 2012 & Montserrat 1997 (effusive inferred*), UK \\
\hline Giachetti et al. 2010 & Montserrat 1997 (effusive inferred*), UK \\
\hline Shea et al., 2010b & Makapu'u 1.8-2.8 Ma, Hawaii, USA \\
\hline
\end{tabular}

* Inferred values correspond to $\mathrm{N}_{\mathrm{b}}$ only for large bubble population as described in each reference 
Table DR4. Reference list for chemical composition in bubble number density data compilation.

\section{Short Reference for composition Eruption}

Coombs \& Gardner 2001

Fierstein \& Hildreth 1992

Alfano et al., 2011

Lanzo et al., 2013

Sigurdsson \& Sparks 1981

Cioni et al., 2011

Colombier et al., 2017b

Harford et al., 2003

Cioni et al., 1995

Stokes et al., 1992

Blundy \& Cashman 2005

Bacon \& Druitt 1988

Nakamura 2006

Rutherford \& Devine 1996

Polacci et al., 2003

Stewart \& Castro 2016

Rosi et al. 2004

Barker et al., 2013*

Barker et al., 2013*

Barker et al., 2013*

Rotella et al., 2015

Rotella et al., 2015

Rotella et al., 2015

Suzuki \& Nakada 2002
Novarupta 1912, Alaska, USA

Novarupta 1912, Alaska, USA

Chaitén 2008, Chile

Green Tuff Pantelleria 45ka, Italy

Askja 1875, Iceland

Vesuvius 512, Italy

Kilian 9.4 ka, France

Montserrat 1997, UK

Vesuvius 79, Italy

Taupo 181, New Zealand

Mt St Helens 1980, Washington, USA

Mt Mazama 7.7 ka, Oregon, USA

Sakurajima 1914-1915, Japan

Pinatubo 1991, Philippines

Campanian Ignimbrite 39ka, Italy

Quilotoa 800 BP, Ecuador

Quilotoa 800 BP, Ecuador

R-Matatirohia (3.7 ka), New Zealand

R-Oneraki (3.15 ka), New Zealand

R-Fleetwood (2.2 ka), New Zealand

Raoul SW volcano Holocene, New Zealand

Healy (recent), New Zealand

Havre 2012, New Zealand

Usu 2000, Japan

\footnotetext{
* whole rock composition
} 


\section{ADDITIONAL REFERENCES}

\section{Bubble number density compilation}

Adams, N.K., Houghton, B.F. and Hildreth, W. 2006a. Abrupt transitions during sustained explosive eruptions: examples from the 1912 eruption of Novarupta, Alaska. Bulletin of Volcanolgy 69, p. 189-206. doi: 10.1007/s00445-006-0067-4

Adams, N.K., Houghton, B.F., Fagents, S.A. and Hildreth, W. 2006b. The transition from explosive to effusive eruptive regime: The example of the 1912 Novarupta eruption, Alaska. GSA Bulletin May/June 2006, v. 118, no. 5/6, p. 620-634. doi: 10.1130/B25768.1

Alfano, F., Bonadonna, C. and Gurioli, L. 2012. Insights into eruption dynamics from textural analysis: the case of the May, 2008, Chaitén eruption. Bulletin of Volcanolgy 74, p. 2095-2108. doi: 10.1007/s00445-012-0648-3

Cáceres, F., Castruccio, Á. and Parada, M. A. 2018. Morphology, effusion rates, and petrology of postglacial lavas of Laguna del Maule Volcanic Field, Chilean Andes, and implications for their plumbing system. Geochemistry, Geophysics, Geosystems 19, 4925-4944. doi: 10.1029/2018GC007817

Campagnola, S., Romano, C., Mastin, L.G. and Vona, A. 2016. Confort 15 model of conduit dynamics: applications to Pantelleria Green Tuff and Etna 122 BC eruptions. Contributions to Mineralolgy and Petrology 171, 60. doi: 10.1007/s00410-016-1265-5

Carey, R.J., Houghton, B.F. and Thordarson, T. 2009. Abrupt shifts between wet and dry phases of the 1875 eruption of Askja Volcano: Microscopic evidence for macroscopic dynamics. Journal of Volcanology and Geothermal Research 184, p. 256-270. doi: 10.1016/j.jvolgeores.2009.04.003

Cioni, R., Bertagnini, A., Andronico, D., Cole, P.D. and Mundula, F. 2011. The 512 AD eruption of Vesuvius: complex dynamics of a small scale subplinian event. Bulletin of Volcanolgy 73, p. 789-810. doi: 10.1007/s00445-011-0454-3

Colombier, M., Gurioli, L., Druitt, T.H., Shea, T., Boivin, P., Miallier, D. and Cluzel, N. 2017b. Textural evolution of magma during the 9.4-ka trachytic explosive eruption at Kilian Volcano, Chaîne des Puys, France. Bull Volcanol 79:17. doi: 10.1007/s00445-0171099-7

Degruyter, W., Bachmann, O., Burgisser, A. and Manga, M. 2012. The effects of outgassing on the transition between effusive and explosive silicic eruptions. Earth and Planetary Science Letters 349-350, p. 161-170. doi: 10.1016/j.epsl.2012.06.056

Giachetti, T., Druitt, T.H., Burgisser, A., Arbaret, L. and Galven, C. 2010. Bubble nucleation, growth and coalescence during the 1997 Vulcanian explosions of Soufrière Hills Volcano, Montserrat. Journal of Volcanology and Geothermal Research 193, p. 215231. doi: 10.1016/j.jvolgeores.2010.04.001

Gurioli, L., Houghton, B.F., Cashman, K.V. and Cioni, R. 2005. Complex changes in eruption dynamics during the 79 AD eruption of Vesuvius. Bull Volcanol 67, p. 144-159. doi: $10.1007 / \mathrm{s} 00445-004-0368-4$ 
Houghton, B.F., Carey, R.J., Cashman, K.V., Wilson, C.J.N., Hobden, B.J. and Hammer, J.E. 2010. Diverse patterns of ascent, degassing, and eruption of rhyolite magma during the 1.8 ka Taupo eruption, New Zealand: Evidence from clast vesicularity. Journal of Volcanology and Geothermal Research 195, p. 31-47. doi: 10.1016/j.jvolgeores.2010.06.002

Klug, C. and Cashman, K.V. 1994. Vesiculation of May 18, 1980, Mount St. Helens magma. $\begin{array}{lllll}\text { Geology } 22, & \text { p. } & 468-472 . & \text { doi: }\end{array}$ 7613(1994)022<0468:VOMMSH>2.3.CO;2

Klug, C., Cashman, K.V. and Bacon, C.R. 2002. Structure and physical characteristics of pumice from the climactic eruption of Mount Mazama (Crater Lake), Oregon. Bull Volcanol 64, p. 486-501. doi: 10.1007/s00445-002-0230-5

Nakamura, K. 2006. Textures of plagioclase microlite and vesicle within volcanic products of the 1914-1915 eruption of Sakurajima Volcano, Kyushu, Japan. Journal of Mineralogical and Petrological Sciences 101, p. 178-198. doi: 10.2465/jmps.101.178

Polacci, M., Papale, P. and Rosi, M. 2001. Textural heterogeneities in pumices from the climactic eruption of Mount Pinatubo, 15 June 1991, and implications for magma ascent dynamics. Bull Volcanol 63, p. 83-97. doi: 10. I007/s004450000123

Polacci, M., Pioli, L. and Rosi, M. 2003. The Plinian phase of the Campanian Ignimbrite eruption (Phlegrean Fields, Italy): evidence from density measurements and textural characterization of pumice. Bull Volcanol 65, p.418-432. doi: 10.1007/s00445-0020268-4

Rosi, M., Landi, P., Polacci, M., Di Muro, A. and Zandomeneghi, D. 2004. Role of conduit shear on ascent of the crystal-rich magma feeding the 800-year-B.P. Plinian eruption of Quilotoa Volcano (Ecuador). Bull Volcanol 66, p. 307-321. doi: 10.1007/s00445-0030312-z

Rotella, M.D., Wilson, C.J.N., Barker, S.J., Cashman, K.V., Houghton, B.F. and Wright, I.C. 2014. Bubble development in explosive silicic eruptions: insights from pyroclast vesicularity textures from Raoul volcano (Kermadec arc). Bull Volcanol 76:826. doi: 10.1007/s00445-014-0826-6

Rotella, M.D., Wilson, C.J.N., Barker, S.J., Schipper, C.I., Wright, I.C. and Wysoczanski, R.J. 2015. Dynamics of deep submarine silicic explosive eruptions in the Kermadec arc, as reflected in pumice vesicularity textures. Journal of Volcanology and Geothermal Research 301, p. 314-332. doi: 10.1016/j.jvolgeores.2015.05.021

Shea, T., Gurioli, L., Larsen, J.F., Houghton, B.F., Hammer, J.E. and Cashman, K.V. 2010a. Linking experimental and natural vesicle textures in Vesuvius 79AD white pumice. Journal of Volcanology and Geothermal Research 192, p. 69-84. doi: 10.1016/j.jvolgeores.2010.02.013

Shea, T., Houghton, B.F., Gurioli, L., Cashman, K.V., Hammer, J.E. and Hobden, B.J. 2010b. Textural studies of vesicles in volcanic rocks: An integrated methodology. Journal of Volcanology and Geothermal Research 190, p. 271-289. doi: 10.1016/j.jvolgeores.2009.12.003 
Shea, T., Gurioli, L. and Houghton, B.F. 2012.Transitions between fall phases and pyroclastic density currents during the AD 79 eruption at Vesuvius: building a transient conduit model from the textural and volatile record. Bull Volcanol 74, p. 2363-2381. doi: $10.1007 / \mathrm{s} 00445-012-0668-\mathrm{z}$

Shea, T. 2017. Bubble nucleation in magmas: A dominantly heterogeneous process? Journal of Volcanology and Geothermal Research 343, p. 155-170. doi: 10.1016/j.jvolgeores.2017.06.025

Suzuki, Y. and Nakada, S. 2002. Vesiculation and magma ascent process in the Usu 200 eruption, inferred from texture and size distribution of bubble. Bulletin of the Volcanological Society of Japan 47, p. 675-688 (in Japanese with English abstract). doi: 10.18940/kazan.47.5_675

\section{Additional for chemical composition in bubble number density compilation}

Alfano, F., Bonadonna, C., Volentik, A.C.M., Connor, C.B., Watt, S.F.L., Pyle, D.M. and Connor, L.J. 2011. Tephra stratigraphy and eruptive volume of the May, 2008, Chaitén eruption, Chile. Bull Volcanol 73, p. 613-630. doi: 10.1007/s00445-010-0428-x

Bacon, C.R. and Druitt, T.H. 1988. Compositional evolution of the zoned calcalkaline magma chamber of Mount Mazama, Crater Lake, Oregon. Contrib Mineral Petrol 98, p. 224256. doi: doi.org/10.1007/BF00402114

Barker, S.J., Wilson, C.J.N., Baker, J.A., Millet, M-A., Rotella, M.D., Wright, I.C. and Wysoczanski, R.J. 2013. Geochemistry and Petrogenesis of Silicic Magmas in the IntraOceanic Kermadec Arc. Journal of Petrology 54 (2), p. 351-391. doi: 10.1093/petrology/egs071

Blundy, J. and Cashman, K. 2005. Rapid decompression-driven crystallization recorded by melt inclusions from Mount St. Helens volcano. Geology 33 (10), p. 793-796. doi: $10.1130 / \mathrm{G} 21668.1$

Cioni, R., Civetta, L., Marianelli, P., Metrich, N., Santacroce, R. and Sbrana, A. 1995. Compositional Layering and Syn-eruptive Mixing of a Periodically Refilled Shallow Magma Chamber: the AD 79 Plinian Eruption of Vesuvius. Journal of Petrology 36 (3), p. 739-776. doi: 10.1093/petrology/36.3.739

Coombs, M.L. and Gardner, J.E. 2001. Shallow-storage conditions for the rhyolite of the 1912 eruption at Novarupta, Alaska. Geology 29 (9), p. 775-778. doi: 10.1130/00917613(2001)029<0775:SSCFTR>2.0.CO;2

Fierstein, J. and Hildreth, W. 1992. The plinian eruptions of 1912 at Novarupta, Katmai National Park, Alaska. Bull Volcanol 54, p.646-684. doi: 10.1007/BF00430778

Harford, C.L., Sparks, R.S.J. and Fallick, A.E. 2003. Degassing at the Soufriere Hills Volcano, Montserrat, Recorded in Matrix Glass Compositions. Journal of Petrology 44 (8), p. 1503-1523. doi: 10.1093/petrology/44.8.1503

Lanzo, G., Landi, P. and Rotolo, S.G. 2013. Volatiles in pantellerite magmas: A case study of the Green Tuff Plinian eruption (Island of Pantelleria, Italy). Journal of Volcanology and Geothermal Research 262, p. 153-163. doi: 10.1016/j.jvolgeores.2013.06.011 
Rutherford, M.J. and Devine, J.D. 1996. Preeruption Pressure-Temperature Conditions and Volatiles in the 1991 Dacitic Magma of Mount Pinatubo. In: Newhall, C.G., Punongbayan, R.S. (eds.). 1996. Fire and Mud. Eruptions and Lahars of Mount Pinatubo, Philippines. University of Washington Press, Seattle, pp. 751-766.

Sigurdsson, H. and Sparks, R.S.J. 1981. Petrology of Rhyolitic and Mixed Magma Ejecta from the 1875 Eruption of Askja, Iceland. Journal of Petrology 22 (Part 1), p. 41-84. doi: 10.1093/petrology/22.1.41

Stewart, A-M. and Castro, J.M. 2016. P-T-X evolution of the 1280 AD Quilotoa dacite. Journal of Volcanology and Geothermal Research 313, p. 29-43. doi: 10.1016/j.jvolgeores.2015.11.024

Stokes, S., Lowe, D.J. and Froggatt, P.C. 1992. Discriminant function analysis and correlation of Late Quaternary rhyolitic tephra deposits from Taupo and Okataina volcanoes, New Zealand, using glass shard major element composition. Quaternary International 13-14, p. 103-117. doi: 10.1016/1040-6182(92)90016-U

\section{Others}

Casas, A.S., Wadsworth, F.B., Ayris, P.M., Delmelle, P., Vasseur, J., Cimarelli, C., and Dingwell, D.B. 2019. SO2 scrubbing during percolation through rhyolitic volcanic domes. Geochimica et Cosmochimica Acta 257, 150-162. doi: 10.1016/j.gca.2019.04.013

Di Genova, D., Sicola, S., Romano, C., Vona, A., Fanara, S. and Spina, L. 2017b. Effect of iron and nanolites on Raman spectra of volcanic glasses: A reassessment of existing strategies to estimate the water content. Chemical Geology 475, p. 76-86. doi: 10.1016/j.chemgeo.2017.10.035

Hess, K-U. and Dingwell, D.B. 1996. Viscosities of hydrous leucogranitic melts: A nonArrhenian model. American Mineralogist 81, p. 1297-1300. doi: 10.2138/am-1996-91031

Liu, Y., Zhang, Y. and Behrens, H. 2005. Solubility of H2O in rhyolitic melts at low pressures and a new empirical model for mixed $\mathrm{H} 2 \mathrm{O}-\mathrm{CO} 2$ solubility in rhyolitic melts. Journal of Volcanology and Geothermal Research 143, p. 219-235. doi: 10.1016/j.jvolgeores.2004.09.019

Mastin, L. G. 2002. Insights into volcanic conduit flow from an open-source numerical model. Geochemistry, Geophysics, Geosystems 3 (7). doi: 10.1029/2001GC000192

Shea, T., Houghton, B.F., Gurioli, L., Cashman, K.V., Hammer, J.E. and Hobden, B.J. 2010. Textural studies of vesicles in volcanic rocks: An integrated methodology. Journal of 
Volcanology and Geothermal Research 190, p. 271-289. doi: 10.1016/j.jvolgeores.2009.12.003

Tuffen, H. and Castro, J.M. 2009. The emplacement of an obsidian dyke through thin ice: Hrafntinnuhryggur, Krafla Iceland. Journal of Volcanology and Geothermal Research 185, p. 352-366. doi: 10.1016/j.jvolgeores.2008.10.021 